DR. ADRIAN DEOANCA (Orcid ID : 0000-0001-5101-2720)

Article type: Book Review

Author affiliation/address : University of Michigan (Ann Arbor, U.S.A.)

Author email : adeoanca@umich.edu

Martinez, Francisco and Patrick Laviolette (eds.) 2019. Repair, Brokenness, Breakthrough:

Ethnographic Responses. New York and Oxford: Berghahn Books. 340 pp. Hb.: \$105. ISBN 978-1-78920-331-8.

Repair is the mundane practice of putting what is worn out or broken into some form of working order. Hidden beneath a lack of apparent glamour lie cultural and political meanings that afford promising avenues for social analysis. How do perceptions of brokenness and practices of fixing vary culturally? What values, feelings, and aspirations animate acts of maintenance and repair? What are ethical drives and the social and political consequences of mending stuff? Repair, Brokenness, Breakthrough is the first installment of a timely thematic collection of books that seeks to investigate contemporary social imaginaries and the micro-politics of everyday life through the analytic lens of human responses to processes of decay, failure, and breakdown.

Francisco Martinez and Patrick Laviolette, who also serve as editors of the Politics of Repair series, have curated a volume that emphasizes the generative power of breakdown and offers a provisional mapping of approaches for making sense of it. For this reason, the contributions are not held together by any singular theoretical paradigm (material and cultural

This is the author manuscript accepted for publication and has undergone full peer review but has not been through the copyediting, typesetting, pagination and proofreading process, which may lead to differences between this version and the Version of Record. Please cite this article as doi: $\underline{10.1111 / 1469-8676.12773}$

This article is protected by copyright. All rights reserved 
studies viewpoints cohabit peacefully with STS-inspired scholarship) but by a shared ethnographic vantage point into the forms of life that emerge out of moments of breaking. Ethnographies investigate ordinary affects and moral values associated with breakdown; how maintenance and repair enable subjects to fashion ethical selves and to connect with others and with the environment; as well as the aesthetic and spatiotemporal forms that these processes beget.

The volume is divided into twelve chapters bound by an introduction and an epilogue each authored by one of the editors. Topics covered include, among many others, artificial reefing in Florida (Reno), the love of things (Errázuriz), decay and hope (Frederiksen), postSoviet infrastructures (Khalvashi, Sgibnev), waste collection (Tschoepe), and environmental activism (Berglund). A final chapter by Adam Drazin that advocates for thinking about brokenness and repair in terms of belonging and alterity doubles as a theoretical conclusion to the volume. Faithful to the idea that disruption of entrenched orders spurs innovation, the book takes on an experimental structure. Thirteen vignettes interspersed with the more elaborate chapters act as evocative micro-illustrations of social affects. Readers will find endearing the antics of a Spanish octogenarian who plays tricks on telecare services, empathize with a Romanian woman's struggles with pesky bobbles erupting on her garments, and gasp at Jason Pine's disquieting personal meditation on disappearing oneself.

Kathleen Stewart's presence among the contributors - writing of what enlivens nonplaces along American motorways - signals this anthology's concern with hidden affects that animate ordinary life. Care and the practical forms of responsibility it informs is one such affect that several chapters explore by tracing the social relations objectified in material culture. Love informs the intergenerational preservation of dear things in Errázuriz's grandmother's house in Santiago de Chile. Frederiksen's story of Drago, a Bulgarian father, points to abandonment as manifestation of love. The man deliberately avoids fixing his vacated house, for that would be acknowledging his daughter never returning. Both holding on to things and letting go of them represent modes of attachment and belonging.

If the examples above illustrate how objects actualize the past and encode hopes for the future, chapters by Tamta Khalvashi and Aylin Yildirim Tschoepe highlight the creativity involved in dealing with a perpetually precarious present. The introduction of pre-paid coinoperated elevators as pragmatic-moral solutions to perpetual disrepair in Georgia prompted 
residents of high-rises to trick, ransack and vandalize these technical fare-collectors. Likewise, Romani-Turkish informal thrash collectors also have to constantly find ways of transforming their abject identities and of eluding city policies that criminalize their work. The elevators of Tbilisi and the streets of Istanbul are, as Khalvashi puts it, citing Nigel Thrift, 'affective grounds' (p. 109) where morality and belonging are negotiated in relation to spatial enactments of power.

Brokenness and repair emerge out of these accounts as distinctly human modes of being in and acting on the world (a notable exception is the transhumanist sensibility of Joshua Reno's chapter). In Drazin's words, 'the anthropology of repair is [...] profoundly humanist' (p. 298). Nevertheless, the addition of a political-economic perspective on repair qua labor would have contributed to a welcome differentiation of this universalism. Indeed 'we are all repairers,' as Martinez put it, but wage-labor technicians who take care of vital systems bear responsibilities, utilize material repertoires, participate in affective formations, and fashion social relations that differ markedly from those of consumers, the protagonists of the bulk of the book (save for Sgibnev's vignette about transportation workers in Dushanbe). In a time when manual labor is greatly degraded, and when the commons are increasingly abandoned to disrepair, it is imperative to also repair the repairers.

Anthropologists, sociologists, human geographers and STS scholars who research the affective expressions of brokenness and repair will find this book particularly helpful. In discussing social identities and relationships, ethical stances, as well as novel aesthetic and affective formations, this book offers a holistic take on the dialectics of breaking and fixing that is not only intellectually stimulating, but also politically timely. As modernity's promises unravel grimly before our eyes, 'we need,' as Laviolette beseeches us in his epilogue, 'to start existing as well as thinking within paradigms of repair' (p. 322).

\section{ADRIAN DEOANCĂ}

University of Michigan (Ann Arbor, U.S.A.) 